\title{
Seasonal Composition of Lipids, Fatty Acids Pigments in the Brown Alga Sargassum pallidum: The Potential for Health
}

\author{
Natalia Gerasimenko, Stepan Logvinov \\ G.B. Elakov Pacific Institute of Bioorganic Chemistry, Far Eastern Branch, Russian Academy of Sciences, Vladivostok, Russia \\ Email:nigeras.516@gmail.com, gerana@piboc.dvo.ru
}

How to cite this paper: Gerasimenko, N. and Logvinov, S. (2016) Seasonal Composition of Lipids, Fatty Acids Pigments in the Brown Alga Sargassum pallidum: The Potential for Health. Open Journal of Marine Science, 6, 498-523.

http://dx.doi.org/10.4236/ojms.2016.64041

Received: September 12, 2016

Accepted: October 15, 2016

Published: October 18, 2016

Copyright $\odot 2016$ by authors and Scientific Research Publishing Inc. This work is licensed under the Creative Commons Attribution International License (CC BY 4.0).

http://creativecommons.org/licenses/by/4.0/

\section{(c) (i) Open Access}

\begin{abstract}
The present study describes the content of total lipids (TL), the main components of polar and neutral lipids (NL) and photosynthetic pigments (PSP) in edible seaweed Sargassum pallidum (Ochrophyta) from the Sea of Japan, Russia, in different months of the year, taking into account life cycle. Special attention was paid to the fatty acids (FAs) of total lipids as well as the accumulation of important polyunsaturated fatty acids (PUFAs) in glyceroglycolipids (GL) and reserve lipids in the seasonal cycles of growth. The content of TL strongly varied in the course of a year. The major lipid components were GL $(20.3 \%-36.4 \%)$ and NL (19.8\% - 30.6\%), while phospholipids (PL) were present in negligible amounts $(3.2 \%-6.9 \%)$. Significant seasonal variations were observed in content all classes of lipids. The PUFAs prevailed in total lipids and the content of n-6 PUFAs was higher than n-3 PUFAs on all stages of life with the exception of vegetation period. Monogalactosyldiacylglycerols (MGDG) and digalactosyldiacylglecerols (DGDG) were rich in PUFAs and n-3 PUFAs were dominated among them independently of stages of growth. Saturated fatty acids (SFA) were dominated in sulfoquinovosyldiacylglycerols (SQDG). Triacylglycerols (TAG) and diacylglycerols (DAG) contained many PUFAs, especially n-6 PUFAs. Significant concentration 20:3 n-6 was in the triacylglycerols. The concentration of chlorophylls and carotenoids was increased with the growth and maturation of $S$. pallidum and reached maximum in period of highest day length and water temperature. The content of pigments decreased with the onset of short days and decreasing water temperatures. Nutritional value and benefit for health of human this alga were evaluated. The n-6/n-3 PUFAs ratio, nutritional quality index (atherogenic and thrombogenic indices, and ratio between hypocholesterolemic and hypercholesterolemic fatty acids) were low, suggesting a high nutritional value of $S$. pallidum throughout the year.
\end{abstract}




\section{Keywords}

Alga, Lipids, Fatty Acids, Pigments, Nutritional Quality Index

\section{Introduction}

Algae of the genus Sargassum (Ochrophyta) are widely distributed from the temperate to tropical latitudes of the World Ocean and they are actively studied. They demonstrated antioxidant [1]-[3], immune stimulating [2]-[4], and anti-inflammatory activities [5]. In the last decade, many researchers paid attention to Sargassum sp. from nutritional point of view [6]-[11]. Certain species as $S$. fusiforme, $S$. horneri, $S$. pallidum, and $S$. thunbergii used in herbal medicine [12]. A number of publications have demonstrated the attractiveness of PUFAs Sargassum sp. [7], [9] [12]-[20]. PUFAs are used primarily for evaluation nutritional and pharmaceutical characteristics of algae [7], [9], [12], [16], [19], [21], [22]. Other bioactive substances found in Sargassum sp. were monogalactosyldiacylglycerols that showed antifungal [23] and fibrinolytic activities [24]. Sulfoglycerolipid demonstrated antibacterial [25] and antiviral activities [26]. The carotenoid fucoxanthin has an antioxidant and anticancer properties [27], and has shown anti-inflammatory effect [28]-[30]. Seasonal accumulation of these compounds may be of interest for applied purposes. Keen interest in the use of seaweeds as nutraceutical and in pharmaceutical purposes leads to develop artificial cultivation of Sargassum sp. This is particularly well developed in China, where the cultivated $S$. fusiforme, $S$. thunbergii, $S$. fulvellum, $S$. muticum and $S$. horneri, in Korea-S. fusiforme and $S$. fulvellum, and in USA-S. filipendula, $S$. natans, S. fluitans, S. muticum [31] [32]. At the same time the studies of natural algae do not lose relevance. Investigation of composition and content of bioactive substances in local species seaweeds remains an important task in many coastal and island countries. The content of all complexes of compounds as protein, total dietary fiber, ash, lipids was investigated only in a small number of algae. Foremost, seasonal variations in these nutritional components were investigated in $S$. horneri taking into account its growth and maturity, as well as seasonal changes in biomass and moisture was estimated [6]. Seasonal variations of total lipids, fatty acid composition, and fucoxanthin contents in details were investigated also for $S$. horneri [20]. In general, seasonal changes in content of lipids and their components, primarily PUFAs, in several species of red algae [33], green algae [34], and brown algae [20], [35]-[42] were presented. Comparative study of content of phospholipids and glyceroglycolipids [43], and variations fatty acids of these lipids [38] were performed for $S$. pallidum collected only in March and in August, at water temperature $2.9^{\circ} \mathrm{C}$ and $23^{\circ} \mathrm{C}$ respectively. The study the lipid parts of algae stays in a trend as lipids, their fatty acids, carotenoids and sterols are used as functional supplements in human diets, pharmaceuticals, and cosmetics.

In the present work was investigated the dynamics of changes of content of total lipids, and major components polar and neutral lipids, and also pigments in $\mathcal{S}$. pallidum 
in different months of the year taking into account the stages of life cycle. A special attention was paid to the fatty acids of total lipids as well as to the accumulation of important PUFAs in bioactive glyceroglycolipids and neutral lipids (triacylglycerols and diacylglycerols) in the seasonal cycles of growth. Benefit of PUFAs for human health was evaluated by nutritional indices. They were such as the ratio $n-6 / n-3$ PUFAs, and the atherogenic (AI) and the thrombogenic indices (TI), and ratio between hypocholesterolemic and hypercholesterolemic fatty acids $(\mathrm{H} / \mathrm{h})$. Such information has of practical importance to assess the $S$. pallidum with nutritional and pharmaceutical point of view.

\section{Materials and Methods}

\subsection{Plant Material}

Samples of Sargassum pallidum (Turner) C. Agardh (Phaeophyceae, genus Sargassum) were collected from March to December during of 2014 at 0.5 - $2.0 \mathrm{~m}$ depth from Trinity Bay $\left(42^{\circ} 38^{\prime} \mathrm{N}\right.$ and $\left.131^{\circ} 06^{\prime} \mathrm{E}\right)$ Peter the Great Gulf of the Sea of Japan. In this bay is located marine experimental station of the Pacific Institute of Bioorganic Chemistry.

\subsection{Extraction of Lipids}

Algal thalli (5 samples) were cleaned from sand particles and epiphytes and rinsed in running water. Samples were dried out with filter paper and weighed to determine the wet weight (WW), cut into pieces, crushed in a blender and well mixed. Thereafter, 3 samples (each weighing $100 \mathrm{~g}$ ) were taken for drying in an oven at $60^{\circ} \mathrm{C}$ under vacuum to constant weights. A weight dry algae (DW) was determine by the gravimetric method. Extraction was performed by the modified method of Bligh and Dyer [44]. Initially, the sample was extracted twice with methanol and then with chloroform/methanol in ratios of 1:2 and 1:1 (v/v). The extracts were combined, and chloroform was added to a ratio of chloroform-methanol 1:1 ( $\mathrm{v} / \mathrm{v})$. Distilled water was added to form a biphasic system. The chloroform layer was separated and concentrated to dryness in vacuum on a rotary evaporator. Samples of lipids stored at $-25^{\circ} \mathrm{C}$ in hermetic retorts before analysis. The total lipids (TL) content was determined by the gravimetric method as percentage of DW. The moisture content (\%M) of the sample is calculated using the following equation: $\% \mathrm{M}=(\mathrm{WW}-\mathrm{DW} / \mathrm{WW}) \times 100$.

\subsection{Lipids Analysis}

GL content was determined according to the sulfuric-orcinol procedure of Pollet et al. [45] with slight modification. Briefly, thin layer chromatography (TLC) for the GL was carried out on the $12 \times 12 \mathrm{~cm}$ plates covered with silica gel 60F254 (Merck, Germany). The mobile phase was acetone/benzene/water 91:30:8 (v/v/v). Spots corresponding to several classes GL were scraped off the plate in a tubes and sulfuric-orcinol reagent was added. The test tubes were warmed to $80^{\circ} \mathrm{C}$ for $20 \mathrm{~min}$. After centrifugation, the absorbance was measured at $505 \mathrm{~nm}$. MGDG, DGDG, and SQDG were using for constructed of calibration curves. PL was quantified based on the content of phosphorus using molybdate reagent [46]. Neutral lipids were analyzed by TLC on the $12 \times 12 \mathrm{~cm}$ plates 
covered with silica gel 60F254 in developing solvent mixture hexane/diethyl ether/ acetic acid 80:20:1 (v/v/v). The contents of TAG, DAG, and free fatty acids (FFA) were estimated by gas chromatography (GC), using nonadecanoic acid (19:0) as an internal standard [47]. The free sterols content was determined by the Liebermann-Burchard color reaction. The calibration curve was constructed with the fucosterol (Sigma-Aldrich) standard. The optical density was measured in a spectrophotometer (SF2000, Spektr, St. Petersburg, Russia) at $625 \mathrm{~nm}$.

\subsection{Photosynthetic Pigments Contents}

The content of carotenoids and chlorophylls were determined after separation extracts on the plates $10 \times 15 \mathrm{~cm}$ with silica gel 60F254 (Merck, Germany) using of mobile phase hexane/acetone/diethyl ether 50:20:4 ( $/ / \mathrm{v} / \mathrm{v})$. Carotenoids were identified by comparison with authentic standards of fucoxanthin and b-carotene (Sigma-Aldrich). Major carotenoids and chlorophylls bands were scraped off the plate and eluted with chloroform. Absorption maxima $(\max , \mathrm{nm})$ were measured with using the SF 2000 spectrophotometer (Spektr, St. Petersburg, Russia). Quantitative estimates of carotenoids were determined using the following extinction coefficients of E1\% (1 cm path) in ethanol: 2500 for a mixture of pigments at max $450 \mathrm{~nm}$ [48] [49] and 1280 at max 448 $\mathrm{nm}$ for fucoxanthin [50]. The total chlorophylls content was determined using of E1\% 840 (in acetone) at max $663 \mathrm{~nm}[48]$.

\subsection{Lipids of Isolation}

The total lipids were fractionated on silica gel column $(12 \times 2.0 \mathrm{~cm}, 40 / 100 \mu \mathrm{m})$. NL was eluted consequently with $\mathrm{n}$-hexane (fraction 1 ) and solvent mixtures of $\mathrm{n}$-hexane/ diethyl ether (95:5 $\rightarrow$ 50:50, v/v, fractions 2 - 7) and with chloroform (fraction 8). Fraction 1 incorporated b-carotene, wax esters, sterol esters. Fractions 2 and 3 incorporated TAG and FFA at different proportions; fractions 4 - 5-FFA (trace), free sterols and chlorophylls; fractions 6-7-DAG, chlorophylls, fucoxanthin, free sterols (trace); fraction 8-fucoxanthin and other carotenoids. After that the GL were eluted with mixtures of chloroform/acetone $(90: 10 \rightarrow 50: 50, \mathrm{v} / \mathrm{v}$, fractions $9-13)$. Fractions $9-10$ consisted MGDG, MGDG with monogalactosylmonoacylglycerols (MGMG); fraction 11DGDG with betaine lipid and chlorophylls, fractions 12 - 13-SQDG with chlorophylls and trace of PL. The elution process was monitored by TLC with authentic lipid standards of NL and GL. The fractions containing identical substances were combined, dried in vacuum and dissolved in chloroform. TAG and DAG were purified from contaminants by preparative TLC on $12 \times 12 \mathrm{~cm}$ plates with silica gel (silica gel 60F254, Merck, Germany), using developing solvent mixture for NL. MGDG, DGDG and SQDG were purified in a similar way. For MGDG purification using mobile phase acetone/benzene/water in ratio 91:30:4 (v/v/v) and for DGDG and SQDG mobile phase for GL (see above). The classes of lipids were visualized under UV, scraped off in tube with

filter and eluted by chloroform/methanol 2:1 (v/v) from the silica gel. Solvents were drying and prepared fatty acid methyl esters (FAME). 


\subsection{Fatty Acids Methyl Ester Preparation}

FAME was prepared according to the method of Prevot and Mordret [51] with slight modification. Briefly, $2 \mathrm{~mL}$-hexane and $0.4 \mathrm{~mL}$ potassium hydroxide in methanol $2 \mathrm{~N}$ was added to an aliquot of lipids, vortexes for $30 \mathrm{~s}$ and incubated at $50^{\circ} \mathrm{C}$ up to $2 \mathrm{~min}$. Then, $0.4 \mathrm{~mL} 2 \mathrm{~N}$ hydrochloric acid in methanol was added to the solution and vortexes up to $3 \mathrm{~min}$ at room temperature. The mixture was left for 1-2 min. After that, the upper hexane layer containing FAME was recover and crude FAME were purified by TLC using benzene/hexane 30:70 (v/v) as mobile phase and analyzed by GC on GC Shimadzu 2010 Plus (Japan) with a flame ionization detector. Supelcowax 10 column $\left(30 \mathrm{~m} \times 0.25 \mathrm{~mm} \mathrm{ID} \times 0.25 \mu \mathrm{m}\right.$ film, Supelco, USA) was used (isotherm, $210^{\circ} \mathrm{C} ; \mathrm{He}-1$ $\mathrm{mL} \cdot \mathrm{min}^{-1}$; $\mathrm{He}-$ linear velocity, $\left.40 \mathrm{~cm} \cdot \mathrm{sec}^{-1}\right)$. FAME was identified by using equivalent chain length (ECL) values [52]. For determination of double bond, positions were used pirrolidide derivatives ( $N$-acyl pirrolidides). These prepared by direct treatment of FAME with pyrrolidine/acetic acid $10: 1(\mathrm{v} / \mathrm{v})$ at $80^{\circ} \mathrm{C}$ for $45 \mathrm{~min}$ [53] and purified by TLC in mixture hexane/diethyl ether 2:1 (v/v). The pyrrolidides were analyzed by gas chromatography/mass spectrometry (GC/MS) on Agilent 6890 gas chromathograph with quadrupole mass selective detector (MSD) HP 5973 (ionization energy was $70 \mathrm{eV}$ ) and HP-5ms column $(30 \mathrm{~m} \times 0.25 \mathrm{~mm}$ ID $\times 0.25 \mu \mathrm{m}$ film, Agilent, USA). Temperature regime was programmed: $205^{\circ} \mathrm{C}-5 \mathrm{~min}, 5^{\circ} \mathrm{C} \mathrm{m^{-1 }}$ to $240^{\circ} \mathrm{C}, 20^{\circ} \mathrm{C}-30 \mathrm{~min} ; \mathrm{He}-1.3$ $\mathrm{mL} \cdot \mathrm{min}^{-1}$. The solvent delay for pirrolidide derivatives was 3 minutes.

\subsection{Nutritional Indices}

The nutritional quality of the lipids was assessed by considering three indices: atherogenic, thrombogenic, and the ratio between the hypocholesterolemic and hypercholesterolemic fatty acids. AI and TI indices calculated by the method of Ulbricht and Southgate [54]:

$$
\begin{aligned}
& \mathrm{AI}=\mathrm{C} 12: 0+4 \times \mathrm{C} 14: 0+\mathrm{C} 16: 0 / \Sigma \text { MUFAs }+\sum \mathrm{n}-6 \text { PUFAs }+\sum \mathrm{n}-3 \text { PUFAs } \\
& \mathrm{TI}=\mathrm{C} 14: 0+\mathrm{C} 16: 0+\mathrm{C} 18: 0 / 0.5 \times \Sigma \text { MUFAs }+0.5 \times \Sigma \mathrm{n}-6 \text { PUFAs }+3 \times \Sigma \mathrm{n}-3 \text { PUFAs }+
\end{aligned}
$$

Ratio between $\mathrm{H} / \mathrm{h}$ fatty acids calculated by the method Santos-Silva et al. [55]:

$\mathrm{H} / \mathrm{h}=\mathrm{C} 18: 1 \mathrm{n}-9+\mathrm{C} 18: 2 \mathrm{n}-6+\mathrm{C} 20: 3 \mathrm{n}-6+\mathrm{C} 20: 4 \mathrm{n}-6+\mathrm{C} 18: 3 \mathrm{n}-3+\mathrm{C} 20: 5 \mathrm{n}-3+\mathrm{C} 22: 6 \mathrm{n}-3 /$ $\mathrm{C} 14: 0+\mathrm{C} 16: 0$

\subsection{Statistical Analysis}

Mean values (percentage) and their standard deviations (SD) for each component were calculated of three replicate assays using the Microsoft Excel computer program (Microsoft Corp., USA). Figures were built using Microsoft Office Excel.

\section{Results}

\subsection{Seasonal Changes in Moisture Content and Dry Mass}

Seasonal variations in the moisture contents of Sargassum pallidum were in range 75.2\% 82.4\% WW (Figure 1(a)). A weight of dry algae (dry mass) varied in range 17.6\% - 24.8\% 


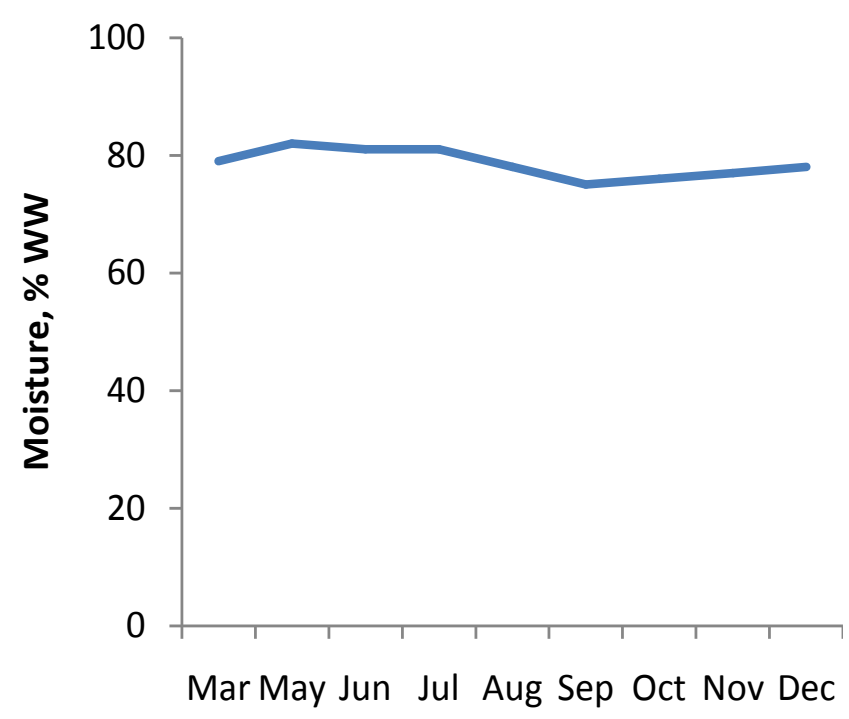

(a)

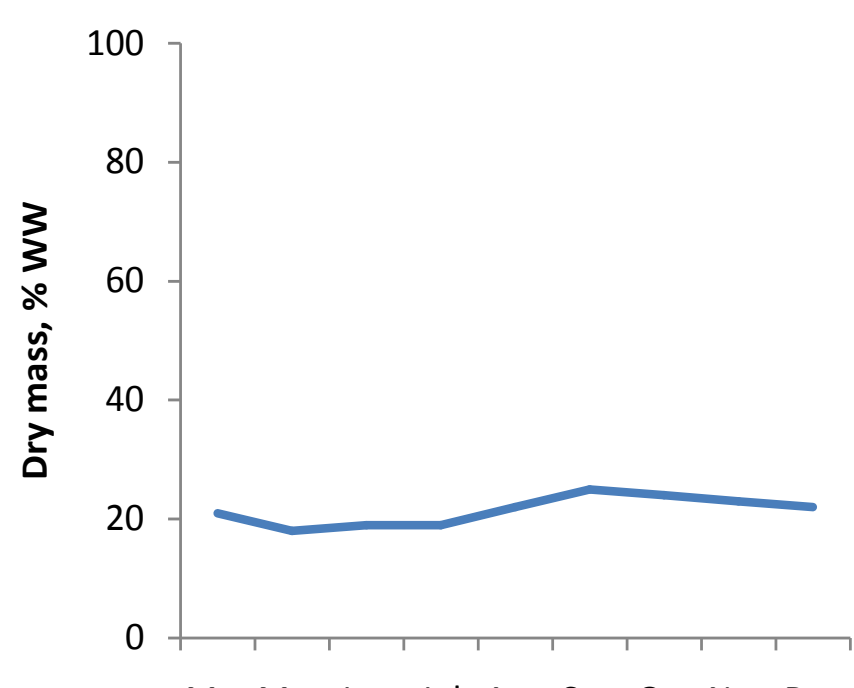

Mar May Jun Jul Aug Sep Oct Nov Dec

(b)

Figure 1. Seasonal variations in the moisture content (a) and dry mass (b) in Sargassum pallidum.

WW Figure 1(b).

\subsection{Seasonal Changes in Total Lipids Contents}

Seasonal changes in content of TL are shown in Table 1 . The lipids content of $S$. pallidum vary significantly throughout the year. They were in a range of $1.99 \%-8.15 \% \mathrm{DW}$ of algae (19.9 - $81.5 \mathrm{mg} / \mathrm{g} \mathrm{DW})$. There was two minimum in TL content: in May (the end of vegetative stage) and in September (after reproduction) and two maximum: in March (after a period of slow growth rate in winter) and June-August (period of growth and maturation, Table 1).

\subsection{Seasonal Changes in Contents of Lipids Classes}

Total lipids include such classes as GL and PL, and NL. There were variations in content all classes of lipids in the course of a year. The glyceroglycolipids identified by TLC were MGDG, DGDG, and SQDG. Minor component was monogalactosylmonoacylglycerols in summer only. GL were the main polar components of TL. Significant variation in GL content throughout the seasons was observed. That was in range $20.3 \%$ $36.4 \%$ of TL (Table 1). SQDG and MGDG were the main components of GL and reached $8.8 \%-17.9 \%$ and $5.3 \%-12.9 \%$ respectively while the level of DGDG was low $(2.7 \%-9.5 \%)$.

The content of PL was 3.2\% - 6.9\% of TL. The highest amounts of PL were present in the alga in November-December and in March.

NL varied in range $19.8 \%-30.6 \%$ of TL. The highest NL values were in March, in August and in November-December. The basic components of the NL were TAG (9.4\% $16.1 \%)$. In $S$. pallidum was determined DAG, which varied from 0.8 to $6.2 \%$ throughhout the year. Free sterols varied in range $4.1 \%-6.4 \%$. TLC identified free fatty acids 
Table 1. The contents of total lipids, classes of lipids and pigments in Sargassum pallidum in different seasons.

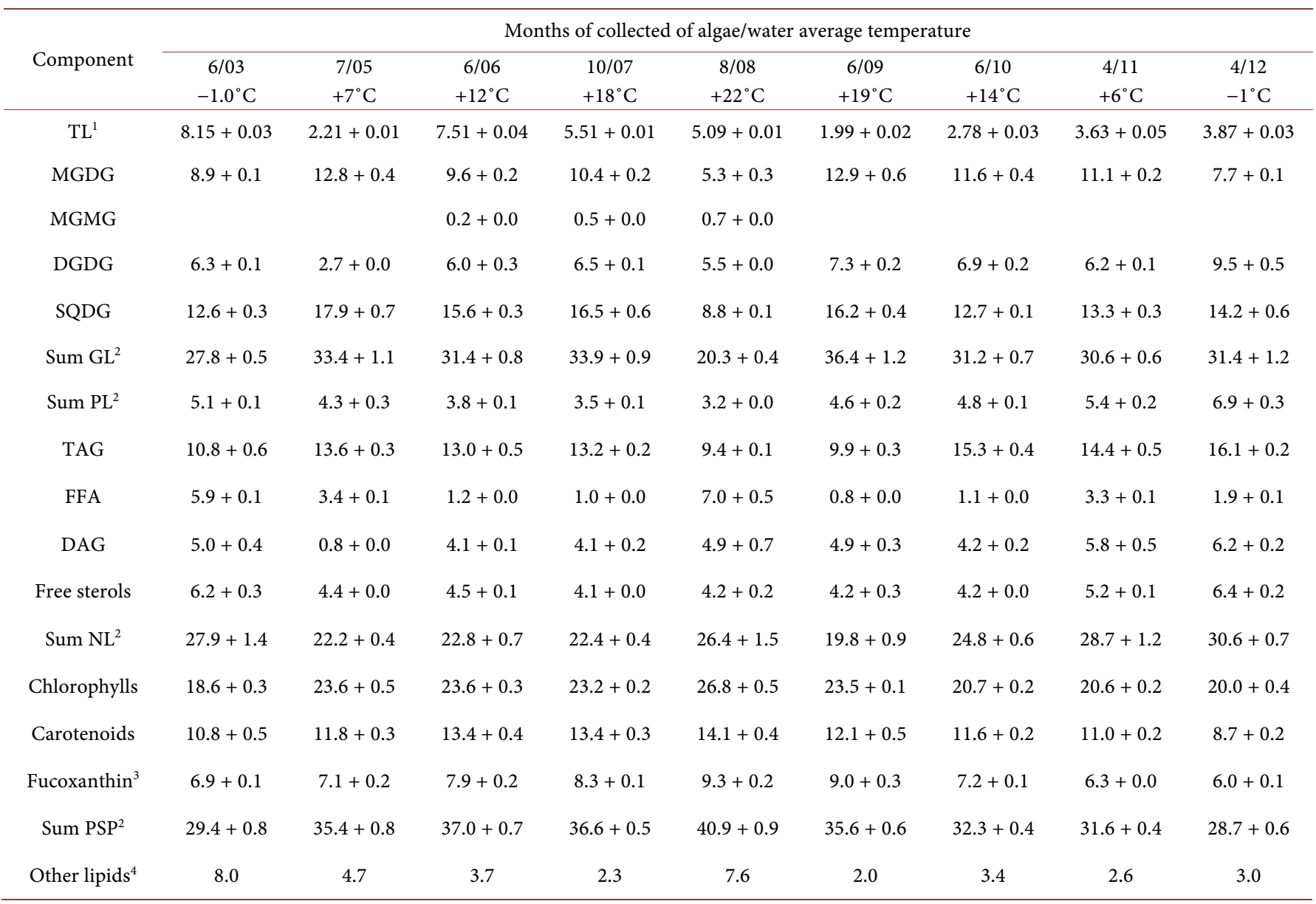

${ }^{1}$ Percentage of dry weight of algae. ${ }^{2}$ Percentage of TL. ${ }^{3}$ Determined only the content of fucoxanthin. ${ }^{4}$ Betaine lipids and non-identified lipids the content of substances are presented as mean values $+\mathrm{SD}$ of three replicate assays.

(FFA). Their contents were in range $0.8 \%-5.9 \%$ of TL.

\subsection{Seasonal Changes in Photosynthetic Pigments Contents}

Seasonal changes in PSP contents are shown in Table 1. The content of chlorophylls varied in range $18.6 \%-26.8 \%$, carotenoids were $8.7 \%-14.1 \%$ of TL throughout the year. The main carotenoid was fucoxanthin that varied in range $6.0 \%-9.3 \%$ in sum carotenoids.

\subsection{Seasonal Variations in Fatty Acids of Total Lipids}

The FAs composition of total lipids is shown in Table 2. In the TL of $S$. pallidum 16:0, $16: 1 n-7,18: 1 n-9,18: 2 n-6,18: 3 n-3,18: 4 n-3,20: 3 n-6,20: 4 n-6$, and 20:5n-3 were the major fatty acids. Palmitic acid 16:0 was the dominating saturated fatty acid in TL throughout the year (Table 2). Variations in the relative amounts of total SFA, total monounsaturated fatty acids (MUFAs), total n-6 PUFAs, and total n-3 PUFAs were in range $22.0 \%-29.1 \%, 13.6 \%-17.3 \%, 29.9 \%-45.9 \%$ and $14.7 \%-33.4 \%$ respectively 
Table 2. Fatty acid composition of the total lipids of Sargassum pallidum in different seasons (expressed as mean values + SD).

\begin{tabular}{|c|c|c|c|c|c|c|c|c|c|}
\hline \multirow{2}{*}{$\begin{array}{c}\text { FAs (as \% of } \\
\text { total FAs) }\end{array}$} & \multicolumn{8}{|c|}{ Months of collected of alga } & \multirow[b]{2}{*}{$4 / 12$} \\
\hline & $6 / 03$ & $7 / 05$ & $6 / 06$ & $10 / 07$ & $8 / 08$ & $6 / 09$ & $6 / 10$ & $4 / 11$ & \\
\hline \multicolumn{10}{|l|}{ SFA } \\
\hline $14: 0$ & $4.1+0.2$ & $4.2+0.2$ & $3.8+0.3$ & $3.6+0.4$ & $3.8+0.6$ & $3.2+0.2$ & $3.5+0.0$ & $5.3+0.0$ & $3.9+0.1$ \\
\hline $15: 0$ & $0.5+0.0$ & $0.3+0.0$ & $0.3+0.0$ & $0.3+0.0$ & $0.2+0.0$ & $0.2+0.0$ & $0.2+0.0$ & $0.3+0.0$ & $0.1+0.0$ \\
\hline $16: 0$ & $22.9+1.0$ & $17.4+0.3$ & $18.2+0.5$ & $17.4+0.3$ & $20.7+0.2$ & $18.4+0.2$ & $20.8+0.0$ & $17.6+0.1$ & $21.8+0.9$ \\
\hline $18: 0$ & $0.2+0.0$ & $0.8+0.0$ & $0.1+0.0$ & $0.5+0.0$ & $0.4+0.0$ & $0.4+0.0$ & $0.7+0.0$ & $0.6+0.0$ & $0.3+0.0$ \\
\hline $20: 0$ & $0.2+0.0$ & $0.2+0.0$ & $0.5+0.0$ & $0.1+0.0$ & $0.3+0.0$ & $0.3+0.0$ & $0.2+0.0$ & $0.3+0.0$ & $0.4+0.0$ \\
\hline $22: 0$ & $1.2+0.0$ & $0.2+0.0$ & $0.4+0.0$ & $0.1+0.0$ & $0.5+0.0$ & $0.1+0.0$ & $0.6+0.0$ & $0.1+0.0$ & $0.8+0.0$ \\
\hline \multicolumn{10}{|l|}{ MUFAs } \\
\hline $16: 1 n-7$ & $7.4+0.1$ & $3.7+0.1$ & $6.5+0.1$ & $6.3+0.2$ & $6.3+0.5$ & $5.8+0.3$ & $6.8+0.5$ & $5.9+0.1$ & $7.0+0.3$ \\
\hline $18: 1 n-7$ & $0.5+0.0$ & $0.6+0.0$ & $0.5+0.0$ & $0.7+0.0$ & $0.6+0.0$ & $0.4+0.0$ & $0.4+0.0$ & $0.1+0.0$ & $0.5+0.0$ \\
\hline $18: 1 n-9$ & $6.4+0.5$ & $7.5+0.5$ & $7.0+0.1$ & $5.3+0.3$ & $5.4+0.6$ & $7.7+0.4$ & $8.5+0.1$ & $9.0+0.2$ & $7.8+0.4$ \\
\hline $20: 1 n-9$ & $1.6+0.0$ & $0.9+0.0$ & $1.0+0.0$ & $1.7+0.1$ & $1.7+0.3$ & $1.1+0.0$ & $1.0+0.0$ & $1.2+0.1$ & $1.0+0.0$ \\
\hline $22: 1 n-9$ & $1.1+0.0$ & $0.9+0.0$ & $1.0+0.0$ & $1.2+0.0$ & $1.2+0.0$ & $0.9+0.0$ & $0.6+0.0$ & $1.0+0.0$ & $0.9+0.0$ \\
\hline \multicolumn{10}{|l|}{ n-6 PUFAs } \\
\hline $16: 2 n-6$ & $0.3+0.0$ & & $0.4+0.0$ & $0.1+0.0$ & $0.5+0.0$ & $0.1+0.0$ & $0.3+0.0$ & $0.8+0.1$ & $0.5+0.0$ \\
\hline $18: 2 n-6$ & $9.1+0.2$ & $9.2+0.4$ & $10.7+0.4$ & $14.4+0.4$ & $15.0+0.3$ & $15.6+0.2$ & $12.5+0.1$ & $11.2+0.1$ & $10.9+0.7$ \\
\hline $18: 3 n-6$ & $1.6+0.2$ & $1.5+0.1$ & $1.5+0.1$ & $1.7+0.1$ & $1.7+0.2$ & $2.2+0.1$ & $2.1+0.3$ & $4.1+0.4$ & $1.2+0.0$ \\
\hline $20: 3 n-6$ & $5.0+0.5$ & $3.8+0.2$ & $3.9+0.0$ & $9.6+0.4$ & $8.1+0.1$ & $6.5+0.3$ & $4.5+0.0$ & $4.7+0.1$ & $6.0+0.2$ \\
\hline $20: 4 n-6$ & $17.6+0.7$ & $15.4+0.4$ & $17.3+0.3$ & $20.1+0.9$ & $18.0+0.6$ & $19.6+0.2$ & $20.0+0.3$ & $13.4+0.1$ & $17.1+0.8$ \\
\hline \multicolumn{10}{|l|}{ n-3 PUFAs } \\
\hline $18: 3 n-3$ & $5.3+0.3$ & $6.8+0.3$ & $6.6+0.5$ & $7.3+0.5$ & $7.6+0.7$ & $5.8+0.3$ & $5.8+0.4$ & $5.1+0.2$ & $5.0+0.3$ \\
\hline $18: 4 n-3$ & $7.0+0.3$ & $11.9+0.6$ & $9.1+0.5$ & $3.6+0.1$ & $3.6+0.1$ & $5.7+0.1$ & $6.4+0.2$ & $8.6+0.2$ & $7.9+0.6$ \\
\hline $20: 5 n-3$ & $5.3+0.3$ & $14.7+0.3$ & $9.8+0.5$ & $3.4+0.1$ & $3.3+0.1$ & $4.9+0.4$ & $4.6+0.1$ & $9.9+0.6$ & $5.4+0.2$ \\
\hline $22: 6 n-3$ & $0.1+0.0$ & & $0.2+0.0$ & $0.5+0.0$ & $0.2+0.0$ & $0.2+0.0$ & & $0.2+0.0$ & $0.1+0.0$ \\
\hline $20: 2 n-9$ & $2.6+0.1$ & & $1.2+0.0$ & $2.1+0.0$ & $0.9+0.0$ & $0.9+0.0$ & $0.5+0.0$ & $0.6+0.0$ & $1.4+0.1$ \\
\hline$\sum$ SFA & $29.1+1.2$ & $23.1+0.5$ & $23.3+0.8$ & $22.0+0.7$ & $25.9+0.8$ & $22.6+0.4$ & $26.0+0.0$ & $24.2+0.1$ & $27.3+1.0$ \\
\hline$\sum$ MUFAs & $17.0+0.6$ & $13.6+0.6$ & $16.0+0.2$ & $15.2+0.6$ & $15.2+1.4$ & $15.9+0.7$ & $17.3+0.6$ & $17.2+0.4$ & $17.2+0.7$ \\
\hline$\sum$ PUFAs & $53.9+2.6$ & $63.3+2.3$ & $60.7+2.6$ & $62.8+2.5$ & $58.9+2.1$ & $61.5+2.0$ & $56.7+1.4$ & $58.6+1.8$ & $55.5+2.9$ \\
\hline$\sum \mathrm{n}-6$ PUFAs & $33.6+1.6$ & $29.9+1.1$ & $33.8+0.8$ & $45.9+1.8$ & $43.3+1.2$ & $44.0+0.8$ & $39.4+0.7$ & $34.2+0.8$ & $35.7+1.7$ \\
\hline$\sum \mathrm{n}-3$ PUFAs & $17.7+0.9$ & $33.4+1.2$ & $25.7+1.5$ & $14.8+0.7$ & $14.7+0.9$ & $16.6+0.8$ & $16.8+0.7$ & $23.8+1.0$ & $18.4+1.1$ \\
\hline$n-6 / n-3$ ratio & 1.89 & 0.89 & 1.31 & 3.10 & 2.95 & 2.65 & 2.35 & 1.43 & 1.94 \\
\hline AI & 0.57 & 0.46 & 0.44 & 0.43 & 0.49 & 0.41 & 0.48 & 0.53 & 0.53 \\
\hline $\mathrm{TI}$ & 0.49 & 0.18 & 0.32 & 0.28 & 0.33 & 0.38 & 0.31 & 0.40 & 0.31 \\
\hline
\end{tabular}

(Table 2). Constantly in TL was dominated unsaturated FAs and among their noticeably higher was percentage PUFAs $(53.9 \%-63.3 \%)$. One more peculiarity of TL is the 
predominance of the n-6 PUFAs (18:2n-6, 20:3n-6, 20:4n-6) over of the n-3 PUFAs. Only in May, TL had higher amount of the n-3 PUFAs than n-6 PUFAs (Table 2).

\subsection{Nutritional Indices of Total Lipids}

N-6/n-3 PUFAs ratio varied in range $0.89-3.10$ (Table 2). The highest n-6/n-3 PUFAs ratios were in July-October $(2.35-3.10)$. AI varied in range $0.41-0.57$, TI-0.18-0.49, $\mathrm{H} / \mathrm{h}-1.80-2.78$ (Table 2).

\subsection{Seasonal Variations in Fatty Acids of Glyceroglycolipids}

MGDG and DGDG showed predominance of PUFAs (Figure 2(a) and Figure 2(b) show the principal FAs). These classes of GL had identical composition of FAs, but significantly differed in the content of the some fatty acids. MGDG and DGDG characterized by the presence of high amounts of n-3 PUFAs as a-linolenic acid 18:3n-3, stearidonic acid 18:4n-3, eicosapentaenoic acid 20:5n-3 and n-6 PUFAs as linoleic acid 18:2n-6 and arachidonic acid 20:4n-6. The content of n-3 PUFAs varied in range $31.2 \%$ - $43.3 \%$ in MGDG and $30.9 \%$ - 48.9\% of total FAs in DGDG. The content of n-6 PUFAs varied in range $19.7 \%-29.5 \%$ in MGDG and $19.9 \%-28.9 \%$ of total FAs in DGDG. The content SFA in MGDG varied in range 19.2-32.5 \% and in DGDG, it was 20.0\% - 27.6\% of total FAs. SQDG contained 49.3-64.1 \% SFA, 20.4-26.7 \% MUFAs and 8.2\% - 15.5\% PUFAs. This GL had greatest content SFA and lowest content PUFAs (Figure 2(c)). 16:0 was the main FA among SFA. All classes GL had noticeable amounts palmitoleic 16:1n-7: in MGDG, it was in range $4.1 \%-6.4 \%$, in DGDG- $1.7 \%-8.6 \%$ and in SQDG- $4.3 \%-11.7 \%$ of total FAs.

\subsection{Seasonal Variations in Fatty Acids of Triacylglycerols and Diacylglycerols}

Seasonal variations in FAs composition of TAG and DAG are present in Figure 3(a) and Figure 3(b). In TAG dominated PUFAs-44.0\% - 73.8\% and n-6 PUFAs were in the first place (Figure 3(a)). Among them 18:2n-6 and 20:4n-6 was the main-12.9\% $23.9 \%$ and $6.8 \%-17.2 \%$ respectively. In addition, TAG was rich in dihomo-gammalinolenic acid 20:3n-6 (3.8\% - 16.6\% of total FAs) compared to other lipids. The content SFA varied in range $13.2 \%-32.8 \%$ and MUFAs was $13.0 \%-25.0 \%$. FA 16:0 (7.4\% 20.4\%) and 18:1n-9 (4.4\% - 15.6\%) dominated in SFA and in MUFAs respectively. DAG had higher level of SFA $(37.7 \%$ - 49.0\%) than TAG and 16:0 (24.9\% - 35.7\% of total FAs) dominated (Figure 3(b)). Percentage of PUFAs in DAG was lower or similar with TAG. FA as $18: 2 \mathrm{n}-6$ varied from $7.3 \%$ to $24 \%, 20: 4 n-6$ from $6.8 \%$ to $29.3 \%$, and 20:3n-6 from $3.8 \%$ to $10.8 \%$ (Figure $3(b)$ ).

\section{Discussion}

\subsection{Seasonal Changes in Moisture Content and Dry Mass}

In general, variations moisture content was not too big (Figure 1(a)). The highest percentage of moisture was in the spring, when the alga was in vegetation, as well as in 


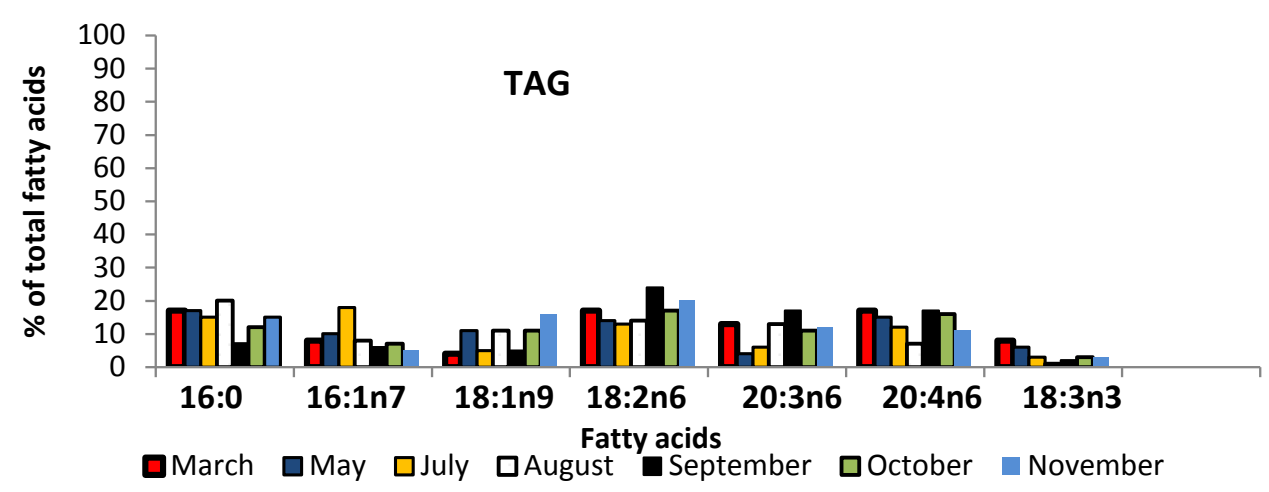

(a)

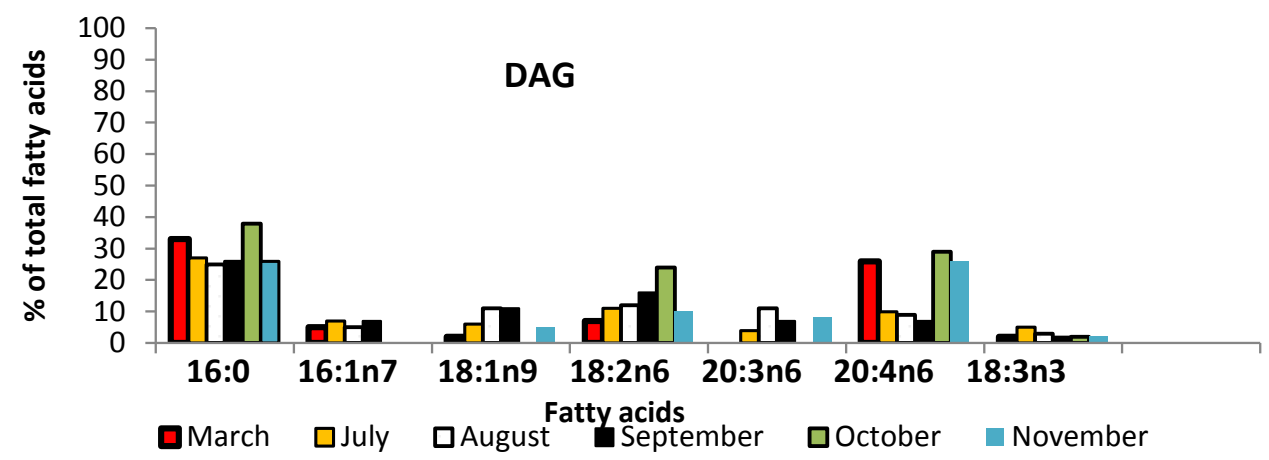

(b)

Figure 3. Monthly variation in major fatty acids TAG (a) and DAG (c) in Sargassum pallidum.

\subsection{Seasonal Changes in Total Lipids Contents}

It is accepted that TL content of algae varies with temperature, light intensity, concentration of nutrients in the water, salinity, etc. [57]. Sargassum sp. of temperate-cold waters showed a relatively higher quantity of TL as compared with these algae from tropical zone. So Sargassum sp. from Bohai Sea accumulates 1.71\% - 1.88\% TL (17.2 - 18.8 $\mathrm{mg} / \mathrm{g}$ on WW) [15] and in seven species of these algae from Gujarat coast India the TL content varied in range $0.57 \%-2.0 \%(5.7-20 \mathrm{mg} / \mathrm{g}$ on WW) [19]. S. natans from tropical seas contains $10 \mathrm{mg} / \mathrm{g}$ TL on DW [7]. Five Sargassum sp. of the coast of Japan contain 27.5 - $62.6 \mathrm{mg} / \mathrm{g}$ TL on DW [39]. The study of seasonal changes in TL content in thalii of $S$. horneri from different habitats of Japan showed an increase in their content from October to January, a slight decrease in April and a further decline in their level until June. The minimum content of lipids (47.4 mg/g DW) was October [20]. On average, TL content reached $102 \mathrm{mg} / \mathrm{g}$ DW. The content of TL in this alga from other location was appreciably higher. It was $142 \mathrm{mg} / \mathrm{g}$ DW [20]. S. horneri of Fukuoka Prefecture (Japan) has no substantial changes in the content of total lipids. A slightly higher content of lipids was shown at the growth of alga (in January and in February, 9.9 - 10.1 $\mathrm{mg} / \mathrm{g}$ of DW), a decrease their content in period maturation (in March and in April, 9.5 and $6.2 \mathrm{mg} / \mathrm{g} \mathrm{DW}$ respectively), the lowest content was in physiologically old algae (5.26 mg/g DW) [6].

Water temperature is one of the most essential factors that may influence the content 
of lipids and especially unsaturated fatty acids in the algae and this factor, in the first place, is regarded by many investigators [20] [33] [35] [37] [43]. The above results showed that such characteristic as content of TL $S$. pallidum of the Russian coasts of the Sea of Japan changes in the course of year and covers all stages of life cycle.

Biomass of $S$. pallidum increases until the winter due to the accumulation of organic and mineral substances; in winter, there is a relatively slow growth rate [58]. At a slow rate of growth, there is a decline in energy requirements. Early March alga had the highest level of lipids (Table 1). In March $S$. pallidum began the vegetative reproduction that was to May. The vegetative stage took place at a water temperature $-1^{\circ} \mathrm{C}+$ $7^{\circ} \mathrm{C}$. Young algae, which were harvested in May, showed nearly fourfold fall in TL content in comparison with March. Main triggers of maturation considered water temperature and day length [59]. The maturation of $S$. pallidum at high rate of growth (growth 1) correlated with water temperature $12^{\circ} \mathrm{C}-22^{\circ} \mathrm{C}$ in June-August. In this period, the content of TL was quite high and remained relatively high in reproductive alga. The minimum level of TL was in September after reproductive phase of algae. In October at water temperature $14^{\circ} \mathrm{C}$ started the next growth phase (growth 2) and the lipid content slightly increased. Then in November and December, the content of TL continued to grow, but the water temperature at the same time decreased to $-1^{\circ} \mathrm{C}$. Thus, the alga $S$. pallidum demonstrated pronounced variations in the content of total lipids associated with changes of seawater temperature. The contents of lipids in different Sargassum sp. of coasts of the Sea of Japan showed general trend to accumulation of lipids in the colder periods and then their variation at stages of life cycle. The level of content TL showed species-specific character and its dependence from geographical location of alga.

\subsection{Seasonal Changes in Contents of Lipids Classes}

GL were major components polar lipids of $S$. pallidum (Table 1). It has long known that glyceroglycolipids of vegetables contribute significantly in the health benefit [60]. MGDG isolated from fresh spinach leaves demonstrate inhibitory effects on tumor promoter-induced Epstein-Barr virus (EBV) activation [61] and exhibited higher antiinflammatory activity than indomethacin, a well-known cyclooxygenase (COX) inhibitor [62]. Galactolipids as shown were responsible for the anti-tumour promoting activity of jute, a well-known medicinal vegetable in North Africa and Asia [63]. Intensive study of algae showed that their GL also exhibit different biological activity, for example, anti-tumour [64] [65], anti-inflammatory [66] [67], antiviral [26], and antibacterial [25] [68] activities that continues to attract attention to these substances. As shown previously, the GL contents in $S$. pallidum were close enough in March and in August [43]. However, we have discovered appreciable variation in GL contents throughout the year. The share of GL increased at the end of vegetation stage in May, when growth started and it remained high until the reproduction. In August alone, at the end ripening of alga, there was considerable decrease content of GL (Table 1). After stage of reproduction the content of GL rises sharply and then starts a fall with decrease water temperature and day length. 
Noted that glycoglycerolipids of chloroplasts of algae, where MGDG and DGDG are the most abundant lipids of thylakoid membrane, plays a crucial role in photosynthesis [69]. Seasonal variations in the contents classes of GL are taking place also. The balance was observed between uncharged MGDG and charged SQDG. The concentrations of MGDG and SQDG are varied simultaneously (Table 1). SQDG prevailed in $S$. pallidum that been characteristically for this alga [70]. This acidic lipid concentrated in outer and in the inner chloroplast thylakoid membrane, where it performs a structural function, SQDG-pigment interaction, and SQDG-protein interaction. Benson [71] supposed that SQDG might assist the orientation chlorophyll molecules in the membranes. Amount of SQDG increased at maturation of chloroplasts [72]. Accumulation SQDG was most noticeable at the end of the vegetation and a period of fast growth $S$. pallidum. At the same time there was an increase in the concentration of chlorophylls (Table 1). We have noticed that the share of DGDG in the TL was relatively low. It varied in different months in a small range, with the exception of May, when the proportion of DGDG was the lowest and in December, when it was highest. Period of reproduction characterized by a decrease of content all classes of GL. It is interesting to note that in the summer months we found very small amounts lysoform MGDG, in particular, MGMG (Table 1). Nuclear magnetic resonance spectroscopy (NMR) we earlier confirmed chemical structure of this lipid as 1-O-acyl-3-O-( $\beta$-D-galactopyranosyl)-sn-glycerols [73]. Increasing all classes of GL observed again after the reproduction.

Share of PL in $S$. pallidum was small in the course of year; however, their content was higher at lower water temperatures in March and November-December (Table 1). As shown earlier, the content of PL is about twice was higher in the winter [43]. Betaine lipid in S. pallidum was present in the course of year at different water temperatures. It should be noted, that TLC has previously showed this lipid in S. pallidum [43] [74], but the structure has not been corroborated. The structure of this lipid from $S$. pallidum was confirmed by NMR as 1,2-diacylglyceryl-3-O-2'(hydroxymethyl)-( $N, N, N$-trimethyl)$\beta$-alanine by us [73].

The highest NL concentrations were found in March, in August and in November-December (Table 1). In NL dominated TAG (Table 1). It is believed that TAG is not only the reserve substances. They easily are involved in the catabolism of cells, where produce the necessary energy, and also participate in the process of adaptation to the environment [75]. TAG accumulation observed from May to July at high rate of growth with increasing biomass, and in October-December, when was the next phase growth (growth 2). This was most likely due to the high concentration of nutrients in the water. The relatively low concentration TAG was in August in reproductive phase and after reproduction in September, probably, due to the energy needs of the reproductive phase and regeneration. Practically the same content of TAG in $S$. pallidum in the winter $\left(\right.$ at $2.9^{\circ} \mathrm{C}$ ) and summer $\left(\right.$ at $23^{\circ} \mathrm{C}$ ) was shown earlier [43]. In S. pallidum we also found of DAG, whose structure confirmed by ${ }^{1} \mathrm{H}$-and ${ }^{13} \mathrm{C}$-NMR spectroscopy as 1 , 2-diacyl-3-hydroxy-sn-glycerols [76]. Appreciable content DAG was detected on all stages life cycle of $S$. pallidum (Table 1 ). It is believed that DAG is required for the 
biosynthesis of SQDG by transferring of sulfoquinovose to diacylglycerol [77]. Information about DAG in brown algae is extremely rare. Only in brown alga Cladosiphon okamuranus this lipid was found [78]. Elevated levels of free fatty acids in March and in August drew attention. In the first case, the algae start the period of vegetation, and in August, the algae have ripe receptacles. The high levels of FFA also have found in some species of algae. For example, in young and actively growing brown alga Egregia menziensii FFA levels reached $18 \%-26 \%$ in winter-spring and in summer-autumn period, they were $0.7 \%-3.5 \%$ of the TL [37]. In the brown alga C. okamuranus FFA were the order of $45 \%$ of the TL [78]. The authors have shown that FFA was the result by the cleavage of both ester bonds of MGDG and DGDG by the action of galactolipase. As the result, significant amounts of the lyso-compounds (MGMG and DGMG) and FFA were presented in lipids. Their FA composition was similar to that in the initial substrate. S. pallidum, as stated above, has very small amounts MGMG in the summer months only.

The content of free sterols in TL of $S$. pallidum was not high. In the colder months in March and in December, the level of free sterols was higher than in the warmer months (Table 1). At the same time, nearly the same content free sterols in $S$. pallidum in the winter and summer was shown earlier [43]. As was noted, in seaweeds of genus Sargassum the percentage of one of the dominant sterols as fucosterol was higher in winter and spring [39].

\subsection{Seasonal Changes in Photosynthetic Pigments Contents}

Environmental conditions, including light intensity, exert influence on algal functional activity and its pigment apparatus. Concentration of PSP in S. pallidum was high and content of chlorophylls was higher than carotenoids approximately twice (Table 1). The photosynthetic efficiency is known to be regulated by changes in chlorophylls content [79]. Their content increased with the growth and maturation of $S$. pallidum [58]. Really, we observed this in the end of the vegetation and in the active growth phase in May-July, when was increase of biomass. Content of chlorophylls reached maximum in August in period of highest day length and water temperature on stage of reproduction. The concentration of carotenoids, photo protective pigments, has also increased at this time (Table 1). Increasing the concentration of products of photosynthesis in summer reduces intensity of photosynthesis with the shortening of day length. We observed that chlorophylls concentration decreased of slightly on growth stage 2 (begins in October) along with the content of carotenoids. Preservation photosynthetic activity at different stages of the life cycle of $S$. pallidum, apparently, is typical of this alga. Therefore probably, on growth stage 2 content of TAG increased significantly (Table 1).

Carotenoids constituted a significant share of low molecular metabolites in the algae genus Sargassum [20] [39] and fucoxanthin was the main component of carotenoids [20] [39] [80] [81]. In Sargassum sp. of the Sea of Japan amounts of fucoxanthin varied from 3.4 up to $5.9 \%$ of total lipids [39]. In S. pallidum, it changed from March to December in the range of $6.0 \%-9.3 \%$ with maximum in summer months and early au- 
tumn (Table 1).

\subsection{Seasonal Variations in Fatty Acids of Total Lipids}

In this section, attention was paid to variations fatty acids throughout the annual life cycle of alga because the water temperature is a signal to the launch of different stages of this cycle. Temperature seawater has a principal effect on the fatty acids composition. Many authors had shown that low temperature of water results in elevated the level of unsaturated fatty acids [35] [82] [83]. At the same time in certain algae was marked relatively constant composition of fatty acids in winter and summer [83] [84]. It was typical for Ascophyllum nodosum, which lives in the northern part of the Atlantic Ocean, where the water temperature not changed radically in the course of a year. Variations in the fatty acids content attributed not only to environmental factors, but they also depended on age and stage of growth of algae as was showed earlier [40] [41].

Table 2 shows the changes in composition of fatty acids of TL. The amount SFA was relatively high at low temperature water in March and December. In addition, it was relatively high in August (water temperature is $22^{\circ} \mathrm{C}$ ) in the reproduction phase, also in October (water temperature is $14^{\circ} \mathrm{C}$ ) in the growth phase 2. Decrease in contents of SFA was observed in the end of vegetation (in May) and before (June and July) and after reproduction (in September) also. The main FAs in MUFAs were 18:1n-9 and $16: 1 \mathrm{n}-7$. It is believed that the increased of oleic acid may be related to sori formation at high water temperature [35]. However in S. pallidum content of 18:1n-9 FA is not increased towards the end of the growth phase, but there is an increase amount of 16:1n-7 relatively of vegetation phase (Table 2). In total lipids were dominated PUFAs (53.9\% 63.3\%, Table 2). Total PUFAs content increased from March to May in vegetative period and was high until the end of the growth phase 1 in July, but in the reproductive phase, there observed decrease. In growth phase 2 (from October), it was lower than in May-July. Peculiarity of this alga was the predominance n-6 PUFAs relatively n-3 PUFAs on all stages of life with the exception of May. In this month, the content n-6 PUFAs decreased, while n-3 PUFAs increased about two fold relatively of March. Among n-6 PUFAs dominated 18:2n-6 and 20:4n-6. FAs 18:3n-3, 18:4n-3, and 20:5n-3 were the main among n-3 PUFAs. Comparative analysis $S$. pallidum from other locations Russian Far Eastern coasts of the Sea of Japan showed that n-6 PUFAs were dominant among FAs, however their levels were lower. So $18: 2 n-6$ and $20: 4 n-6$ was $8.8 \%$ and $17.0 \%$ respectively [13] and from another location they were $9.8 \%$ and $18.0 \%$ respectively [38]. Sum n-3 PUFAs was $19.6 \%$ with dominant $18: 3 n-3$ (8.5\%) and 18:4n-3 (7.3\%) [13]. Sanina et al. [38] obtained results similar to those obtained Khotimchenko [13] for algae collected in August. S. pallidum from the east coast of China had a slight amount of PUFAs (11.8\%), in which was dominated by $18: 2 \mathrm{n}-6(5.0 \%)$ and $20: 4 \mathrm{n}-6$ (3.3\%), but n-3 PUFAs was only 1.7\% [12]. The main FAs of this $S$. pallidum there were SFA and MUFAs: about $61 \%$ and $27 \%$ respectively [12].

Species differences can be noted in the distribution of fatty acids in the total lipids in the course of the year. So, in $S$. horneri the relative percentages of n-3 PUFAs were generally higher in winter, the decline MUFAs occurred in January and April, but there 
were no distinct variations in the SFA and n-6 PUFAs [20].

\subsection{S. pallidum as Source of Important Fatty Acids and His Nutritional Value}

The essential fatty acids linoleic (18:2n-6, LA) and alpha-linolenic (18:3n-3, ALA), which are not synthesized in organisms of animals and humans can only be obtained from food [85]. This is primarily fish and plant foods, vegetable oils of different nature. These FAs are precursors of other fatty acids of this series. FA 18:2n-6 and18:1n-9 is considered as high nutritional because of their protective role against cardiovascular diseases [86]. N-3 PUFAs is also directly connected to preventing of immunologic diseases [87] as well as decreasing chronically neurodegenerative diseases [88], rheumatoid arthritis, osteoporosis [89]. Stearidonic acid (18:4n-3, SA) that constitutes the first metabolite of ALA in the metabolic pathway leading to the endogenous production of eicosapentaenoic acid (20:5n-3, EPA) and docosahexaenoic acid (22:6n-3) [90]. Recently it was suggested that $18: 4 n-3$ itself may be a surrogate for $20: 5 n-3$ for health promotion and disease prevention [91]. Soybean is a rich source of this fatty acid. Recently, several studies indicated that dietary SA more efficiently, than ALA increases EPA. Vegetable oils that containing SA may become a dietary source of n-3 PUFAs that is more effective in increasing tissue n-3 PUFAs concentrations than the current ALA-containing vegetable oils [92]. However, $S$. pallidum is also rich in these PUFA. Algae can complement and even replace the traditional sources since they are rich in PUFAs [93] [94]. As considers van Ginneken [7] marine macroalgae form a good, durable and virtually inexhaustible source for PUFAs with an n-6/n-3 ratio of about 1.0. This ratio that was recommended by the World Health Organization should be less than 10 in order to prevent inflammatory, cardiovascular and nervous system disorders. Apports Nutritionnels Conseilles (France) recommended n-6/n-3 PUFAs ratio 5:1 [95] and NATO workshop-4:1 [96].

N-6/n-3 PUFAs ratios in $S$. pallidum were within these recommendations in the course of a year $(0.89-3.10$, Table 2$)$. Artherogenic and thrombogenic indices were less than one in the course of a year too, owing to the high n-3 PUFAs contents and low $\mathrm{n}-6 / \mathrm{n}-3$ ratios. $\mathrm{H} / \mathrm{h}$ ratios were in range $1.80-2.78$ (Table 2). Low values of AI and TI are more favorable to health because they prevent the emergence of coronary diseases [12]. Moreover, higher ratio between hypocholesterolemic and hypercholesterolemic FAs that observed in the tilapia $(1.56-2.10)$ was considered the more adequate for nutrition [97]. H/h ratios of $S$. pallidum were close to these parameters.

A growing number of studies published in the last two decades, support the view that the foods have extraordinary opportunities to maintain or improve people's health [98], [99]. Algae and their natural components with biological activities can be part of new functional foods.

\subsection{Seasonal Variations in Fatty Acids of Glyceroglycolipids}

Taking into account the importance of the GL as health promoting compounds, we studied fatty acids composition in certain classes of GL and seasonal variations therein 
(Figures 2(a)-(c), we shown the main FAs). Plant glycolipids have a predominance of fatty acids with chain length C18 (18:2n-6 and 18:3n-3). For example, 18:3n-3 accounts for more than $90 \%$ of the total fatty acids of MGDG in leaf and stem vegetables [60]. MGDG and DGDG of $\mathcal{S}$. pallidum include 16:0, 18:1n-9, 18:2n-6, 18:3n-3, 18:4n-3, 20:4n-6, and 20:5n-3 as main components. It should be pointed a high concentration of 16:1n-7 there: $4.1 \%-6.4 \%$ in MGDG and $1.7 \%-8.6 \%$ in DGDG. FA 16:1 was detected in these GL in the range 3.2\% - 4.7\% previously [38]. MGDG and DGDG rich in n-3 PUFAs and n-6 PUFAs (Figure 2(a) and Figure 2(b)), which are considered essential FAs since they are not biosynthesized by mammals and must be taken via food chains. N-3 PUFAs prevailed in MGDG and DGDG irrespective of the temperatures and stages of life. Significant accumulation 18:3n-3 in MGDG was from May to October (Figure 2 (a)). Concentration 18:4n-3 was high throughout the year with the exception of July and August. Accumulation 20:5n-3 was in May-July (Figure 2(a)). In DGDG 18:3n-3 was highest in July-August. Accumulation 18:4n-3 was in March, in May and November-December, and 20:5n-3-in March-July (Figure 2(b)). FA 18:2n-6 in MGDG varied in range $7.3 \%$ - 14.6\%, in DGDG-6.2\% - 12.7\%. FA 20:4n-6 in MGDG varied in range $4.8 \%-11.9 \%$, in DGDG 5.5\% - 13.4\%. SQDG (Figure 2(c)), unlike the first two GL, included many SFA (49.3\% - 64.1\%). MUFAs content was relatively high at all life stages $(20.4 \%-26.7 \%)$ and it was generally higher than in the first GL. PUFAs was not so many $(13.5 \%-29.3 \%)$ and n-6 PUFAs prevailed in them $(8.2 \%-15.5 \%)$.

Earlier investigation of summer-winter changes content fatty acids of MGDG of $S$. pallidum showed accumulation of n-3 PUFAs in winter, while content n-6 PUFAs was similar in both seasons [38]. Content n-3 PUFAs was higher in DGDG than in MGDG and their increase was in winter too. Content n-6 PUFAs was lower in winter. In SQDG, a content n-3 PUFAs was twofold higher in summer and n-6 PUFAs was slightly higher in winter [38].

Amount of MGDG commonly exceeds DGDG in photosynthetic tissues, while DGDG is predominant in non-photosynthetic tissue [100] [101]. Fluctuations in temperature affected the fluidity cytoplasmic and thylakoid membranes. Changing the degree of unsaturation fatty acids GL of $S$. pallidum, the length of their acyl chains allow to regulate membrane fluidity at different environmental conditions that maintain their physiological functions in normal state.

Galactolipids of $S$. pallidum unlike from plants galactolipids, include a significant proportion of both C18 and C20. These lipids of $S$. pallidum can be a source of fatty acids such as 18:2n-6, 20:4n-6, 18:3n-3, 18:4n-3, and 20:5n-3. Such profiles FAs suggest that glyceroglycolipids could have potential benefits for health and interest as the food supplement and in pharmaceutical industry. All classes of GL have a low ratio n-6/n-3 PUFAs. In MGDG, it was in range 0.45 - 0.86, in DGDG 0.41 - 0.69, in SQDG 1.13 1.68. This indicates their high nutritional value.

\subsection{Seasonal Variations in Fatty Acids of Triacylglycerols and Diacylglycerols}

Seasonal variations in fatty acids of TAG and DAG were showed in Figure 3(a) and 
Figure 3(b). As shown earlier, S. pallidum contains many dihomo-gamma-linolenic acid 20:3n-6 [14] that concentrates in the TAG [74]. This FA has attracted increased attention as a precursor of prostaglandin E1 and a number of eicosanoids of high physiological activity [102]. The determination of period accumulation of 20:3n-6 has a practical importance. We found the highest amount of this fatty acid in the period from August to March. Principal fatty acids of TAG were 16:0, 16:1n-7, 18:1n-9, 18:2n-6, 18:3n-3, 20:4n-6 Figure 3(a). Domination PUFAs was typical for TAG. Their content varied in range $44.0 \%-73.8 \%$ and n-6 PUFAs $(34.1 \%$ - 64.6\%) prevailed in PUFAs. Two peaks in the accumulation of PUFAs were found. The first maximum was in March, after slow growth in the winter. The second maximum was in September after reproduction. The highest contents of n-6 PUFAs were in the same period. Lowering the content of PUFAs began in May at the end of the vegetation, and it reached a minimum in the period of reproduction (from $63.1 \%$ to $44.0 \%$ ). The contents of $n-3$ PUFAs were relatively high from March to July (12.0\% - 15.5\%).

FAs compositions of DAG showed considerable differences from that of the TAG Figure 3(b). The level contents of SFA were higher in DAG (37.7\% - 49.0\%) in contrast to TAG (13.2\% - 32.8\%), but total PUFAs in DAG was lower than in TAG. In the DAG also dominated n-6 PUFAs. The percentage of $20: 3 n-6$ in DAG $(3.8 \%-10.8 \%)$ was lower than in the TAG. In March and in October of this fatty acid was not found in DAG. In the DAG in October dominated 18:2n-6, but in March and in OctoberNovember there were 20:4n-6 Figure 3(b).

\section{Conclusion}

In our previous paper, we have shown that total lipids $S$. pallidum some lipid classes and pigments have antimicrobial activity and could find application in medicine and agriculture [68]. In the present work carried out a comprehensive study of the lipid part of the algae at different stages of the life cycle. Seasonal dynamics in the accumulation of different components was identified. The study revealed that in March and in the summer the dry mass in $S$. pallidum is large and that there are a lot of lipids. The alga has appreciable amounts GLs, TAG, and PSP. Like other researchers, we think that the fluctuations in contents of different classes of lipids occur due to the functioning of adaptation mechanisms, which increase the survival of algae in the habitat. The major role belongs to the fatty acids in these processes. Variation in the degree of unsaturation of fatty acids allows the algae to support the phase state of the membranes required for their normal functioning in different conditions of environmental. The determination of seasonal changes in content total lipids and their components, primarily fatty acids, has of practical importance, as this allows selecting the optimal time to harvest of algae. In general, this alga is suitable for the collection throughout the year. Nevertheless, collect is most appropriate in March and summer since it is rich in lipids, and has many PUFAs and carotenoids. With regard to the potential of nutritional application, $S$. pallidum represents suitable source PUFAs with more preferable n-3/n-6 ratios. In addition, this seaweed can be used for the production of fucoxanthin. 


\section{Acknowledgements}

The authors would like to thank of skin-divers and workers of marine experimental station of the Pacific Institute of Bioorganic Chemistry for technical assistance in collecting seaweeds and measurement of water temperatures. We also thank O. Moiseenko for the assistance in the mass spectrometry and A. Esipov for his help at fatty acid identification. The study was supported by Grant of RSCF No. 14-25-00037, Russian Federation.

\section{Conflicts of Interest}

The authors declare there are no conflicts of interests.

\section{References}

[1] Ye, H., Zhou, C., Sun, Y., Zhang, X., Liu, J., Hu, Q. and Zeng, X. (2009) Antioxidant Activities in Vitro of Ethanol Extract from Brown Seaweed Sargassum pallidum. European Food Research and Technology, 230, 101-109. http://dx.doi.org/10.1007/s00217-009-1147-4

[2] Luo, H.-Y., Wang, B., Yu, C.-G., Qu, Y.-L. and Su, C.-L. (2010) Evaluation of Antioxidant Activities of Five Selected Brown Seaweeds from China. Journal of Medicinal Plants Research, 4, 2557-2565. http://dx.doi.org/10.5897/JMPR10.609

[3] Hwang, P.-A., Wu, C.-H., Gau, S.-Y., Chien, S.-Y. and Hwang, D.-F. (2010) Antioxidant and Immune-Stimulating Activities of Hot-Water Extract from Seaweed Sargassum hemiphyllum. Journal of Marine Science and Technology, 18, 41-46.

[4] Zhang, R.-L., Luo, T.-N. and Zhou, S.-K. (2012) Evaluation of Antioxidant and Immunity-Enhancing Activities of Sargassum pallidum Aqueous Extract in Gastric Cancer Rats. Molecules, 17, 8419-8429. http://dx.doi.org/10.3390/molecules17078419

[5] Yang, E.-J., Moon, J.-Y., Kim, S.S., Yang, K.-W., Lee, W.J., Lee, N.H. and Hyun, C.-G. (2014) Jeju Seaweeds Suppress Lipopolysaccharide-Stimulated Proinflammatory Response in RAW 264.7 Murine Macrophages. Asian Pacific Journal of Tropical Biomedicine, 4, 529-537. http://dx.doi.org/10.12980/APJTB.4.2014C1099

[6] Murakami, K., Yamaguchi, Y., Noda, K., Fujii, T., Shinohara, N., Ushirokwa, T., Sugawa-Katayama, Y. and Katayama, M. (2011) Seasonal Variation in the Chemical Composition of a Marine Brown Alga, Sargassum horneri (Turner) C. Agardh. Journal of Food Composition and Analysis, 24, 231-236. http://dx.doi.org/10.1016/j.jfca.2010.08.004

[7] Van Ginneken, V.J.T., Helsper, J.P.F.G., de Visser, W., van Keulen, H. and Brandenburg, W.A. (2011) Polyunsaturated Fatty Acids in Various Macroalgal Species from North Atlantic and Tropical Seas. Lipids in Health and Disease, 10, 104-111. http://dx.doi.org/10.1186/1476-511X-10-104

[8] Hafting, J.T., Critchley, A.T., Cornish, M.L., Hubley, S.A. and Archibald, A.F. (2012) On-Land Cultivation of Functional Seaweed Products for Human Usage. Journal of Applied Phycology, 24, 385-392. http://dx.doi.org/10.1007/s10811-011-9720-1

[9] Pereira, H., Barreira, L., Figueiredo, F., Custódio, L., Vizetto-Duarte, C., Polo, C., Rešek, E., Engelen, A. and Varela, J. (2012) Polyunsaturated Fatty Acids of Marine Macroalgae: Potential for Nutritional and Pharmaceutical Applications. Marine Drugs, 10, 1920-1935. http://dx.doi.org/10.3390/md10091920

[10] Nazni, P. and Renuga (2015) Nutrient Composition of the Selected Brown Seaweeds from Mandapam Coastal Regions; Southeast Coast of India. International Journal of Agricultural 
Food Science, 5, 38-42.

[11] Park, S.Y., Seo, I.S., Lee, S.J. and Lee, S.P. (2015) Study on the Health Benefits of Brown Algae (Sargassum muticum) in Volunteers. Journal of Food Nutrition Research, 3, 126-130. http://dx.doi.org/10.12691/jfnr-3-2-9

[12] Chen, Z., Xu, Y., Liu, T., Zhang, L., Liu, H. and Guan, H. (2016) Comparative Studies on the Characteristic Fatty Acid Profiles of Four Different Chinese Medicinal Sargassum Seaweeds by GC-MS and Chemometrics. Marine Drugs, 14, 68-79. http://dx.doi.org/10.3390/md14040068

[13] Khotimchenko, S.V. (1991) Fatty Acid Composition of Seven Sargassum Species. Phytochemistry, 30, 2639-2641. http://dx.doi.org/10.1016/0031-9422(91)85113-e

[14] Zhukova, N.V. and Svetashev, V.I. (1999) A High Level of Dihomogammalinolenic Acid in Brown Alga Sargassum pallidum (Turn). Phytochemistry, 50, 1209-1211. http://dx.doi.org/10.1016/S0031-9422(98)00662-1

[15] Li, X., Fan, X., Han, L. and Lou, H. (2002) Fatty Acids of Some Algae from the Bohai Sea. Phytochemistry, 59, 157-161. http://dx.doi.org/10.1016/S0031-9422(01)00437-X

[16] Narayan, B., Miyashita, K. and Yosakawa, M. (2005) Comparative Evaluation of Fatty Acid Composition of Different Sargassum (Fucales, Phaeophyta) Species Harvested from Temperate and Tropical Waters. Journal of Aquatic Food Product Technology, 13, 53-70. http://dx.doi.org/10.1300/J030v13n04 05

[17] Gosch, B.J., Magnusson, M., Paul, N.A. and de Nys, R. (2012) Total Lipid and Fatty Acid Composition of Seaweeds for the Selection of Species for Oil-Based Biofuel and Bioproducts. GCB Bioenergy, 4, 919-930. http://dx.doi.org/10.1111/j.1757-1707.2012.01175.x

[18] Silva, G., Pereira, R.B., Valentao, P., Andrade, P.B. and Sousa, C. (2013) Distinct Fatty Acid Profile of Ten Brown Macroalgae. Revista Brasileira de Farmacognosia, 23, 608-613. http://dx.doi.org/10.1590/s0102-695x2013005000048

[19] Kumari, P., Bijo, A.J., Mantri, V.A., Reddy, C.R.K. and Jha, B. (2013) Fatty Acid Profiling of Tropical Marine Macroalgae: An Analysis from Chemotaxonomic and Nutritional Perspectives. Phytochemistry, 86, 44-56. http://dx.doi.org/10.1016/j.phytochem.2012.10.015

[20] Nomura, M., Kamogawa, H., Susanto, E., Kawagoe, Ch., Yasui, H., Saga, N., Hosokawa, M. and Miyashita, K. (2013) Seasonal Variation of Total Lipids, Fatty Acid Composition, and Fucoxanthin Contents of Sargassum horneri (Turner) and Cystoseira hakodatensis (Yendo) from the Northern Seashore of Japan. Journal of Applied Phycology, 25, 1159-1169. http://dx.doi.org/10.1007/s10811-012-9934-x

[21] Patarra, R.F., Leite, J., Pereira, R., Baptista, J. and Neto, A.I. (2013) Fatty Acid Composition of Selected Macrophytes. Natural Product Research, 27, 665-669. http://dx.doi.org/10.1080/14786419.2012.688048

[22] Paiva, L., Lima, E., Patarra, R.F., Neto, A.I. and Baptista, J. (2014) Edible Azorean Macroalgae as Source of Rich Nutrients with Impact on Human Health. Food Chemistry, 164, 128-135. http://dx.doi.org/10.1016/j.foodchem.2014.04.119

[23] Kim, Y.H., Kim, E.H., Lee, C., Kim, M.H. and Rho, J.R. (2007) Two New Monogalactosyl Diacylglycerols from Brown Alga Sargassum thunbergii. Lipids, 42, 395-399. http://dx.doi.org/10.1007/s11745-007-3035-7

[24] Wu, W., Hasumi, K., Peng, H., Hu, X., Wang, X. and Bao, B. (2009) Fibrinolytic Compounds Isolated from a Brown Alga, Sargassum fulvellum. Marine Drugs, 7, 85-94. http://dx.doi.org/10.3390/md7020085

[25] Arunkumar, K., Selvapalam, N. and Rengasamy, R. (2005) The Antibacterial Compound Sulphoglycerolipid 1-0 Palmitoyl-3-0-(6'-sulpho- $\alpha$-quinovopyranosyl)-glycerol from Sar- 
gassum wightii Greville (Phaeophyceae). Botanica Marina, 48, 441-445.

http://dx.doi.org/10.1515/bot.2005.058

[26] Plouguerné, E., de Souza, L.M., Sassaki, G.L., Cavalcanti, J.F., Romanos, M.T.V., da Gama, B.A.P., Pereira, R.C. and Barreto-Bergter, E. (2013) Antiviral Sulfoquinovosyldiacylglycerols (SQDGs) from the Brazilian Brown Seaweed Sargassum vulgare. Marine Drugs, 11, 4628-4640. http://dx.doi.org/10.3390/md11114628

[27] Ayyad, S.E., Ezmirly, S.T., Basaif, S.A., Alarif, W.M., Badria, A.F. and Badria, F.A. (2011) Antioxidant, Cytotoxic, Antitumor, and Protective DNA Damage Metabolites from the Red Sea Brown Alga Sargassum sp. Pharmacognosy Research, 3, 160-165.

http://dx.doi.org/10.4103/0974-8490.85000

[28] Heo, S.J., Yoon, W.J., Kim, K.N., Ahn, G.N., Kang, S.M., Kang, D.H., Affan, A., Oh, C., Jung, W.K. and Jeon, Y.J. (2010) Evalution of Anti-inflammatory Effect of Fucoxanthin Isolated from Brown Algae in Lipopolysaccharide-Stimulated RAW 264.7 Macrophages. Food and Chemical Toxicology, 48, 2045-2051. http://dx.doi.org/10.1016/j.fct.2010.05.003

[29] Chae, D., Manzoor, Z., Kim, S.C., Kim, S., Oh, T.-H., Yoo, E.-S., Kang, H.-K., Hyun, J.-W., Lee, N.H., Ko, M.-H. and Koh, Y.-S. (2013) Apo-9'-Fucoxanthinone, Isolated from Sargassum muticum, Inhibits CpG-Induced Inflammatory Response by Attenuating the Mitogen-Activated Protein Kinase Pathway. Marine Drugs, 11, 3272-3287. http://dx.doi.org/10.3390/md11093272

[30] Yang, E.J., Ham, Y.M., Lee, W.J., Lee, N.H. and Hyun, C.G. (2013) Anti-Inflammatory Effects of Apo-9'-Fucoxanthinone from the Brown Alga, Sargassum muticum. DARU Journal of Pharmaceutical Sciences, 21, 62-68. http://dx.doi.org/10.1186/2008-2231-21-62

[31] Xie, E.Y., Liu, D.C., Jia, C., Chen, X.L. and Yang, B. (2013) Artificial Seed Production and Cultivation of the Edible Brown Alga Sargassum naozhouense Tseng et Lu. Journal of Applied Phycology, 25, 513-522. http://dx.doi.org/10.1007/s10811-012-9885-2

[32] Redmond, S., Kim, J.K., Yarish, C., Pietrak, M. and Bricknell, I. (2014) Culture of Sargassum in Korea: Techniques and Potential for Culture in the U.S. Orono, ME: Maine Sea Grant College Program. http://seagrant.umaine.edu/extension/korea-aquaculture

[33] Kendel, M., Couzinet-Mossion, A., Vian, M., Fleurence, J., Baranathan, G. and Wielgosz-Collin, G. (2013) Seasonal Composition of Lipids, Fatty acids, and Sterols in the Edible Alga Grateloupia turuturu. Journal of Applied Phycology, 25, 425-432. http://dx.doi.org/10.1007/s10811-012-9876-3

[34] Blazina, M., Ivesa, L. and Najdek, M. (2009) Caulerpa racemosa: Adaptive Varieties Studied by Fatty Acid Composition (Northern Adriatic Sea, Vrsar, Croatia). European Journal of Phycology, 44, 183-189. http://dx.doi.org/10.1080/09670260802428250

[35] Honya, M., Kinoshita, T., Ishikawa, M., Mori, H. and Nisizawa, K. (1994) Seasonal Variation in the Lipid Content of Culture Laminaria japonica: Fatty Acids, Sterols, $\beta$-Carotene and Tocopherol. Journal of Applied Phycology, 6, 25-29.

http://dx.doi.org/10.1007/BF02185900

[36] Kim, M.K., Dubacq, J.P., Thomas, J.C. and Giraud, G. (1996) Seasonal Variations of Triacylglycerols and Fatty Acids in Fucus serratus. Phytochemistry, 43, 49-55.

http://dx.doi.org/10.1016/0031-9422(96)00243-9

[37] Nelson, M.M., Phleger, C.F. and Nichols, P.D. (2002) Seasonal Lipid Composition in Macroalgae of the Northeastern Pacific Ocean. Botanica Marina, 45, 58-65. http://dx.doi.org/10.1515/BOT.2002.007

[38] Sanina, N.M., Goncharova, S.N. and Kostetsky, E.Y. (2008) Seasonal Changes of Fatty Acid Composition and Thermotrophic Behavior of Polar Lipids from Marine Macrophytes. 
Phytochemistry, 69, 1517-1527. http://dx.doi.org/10.1016/j.phytochem.2008.01.014

[39] Terasaki, M., Hirose, A., Narayan, B., Baba, Y., Kawagoe, C., Yasui, H., Saga, N., Hosokawa, M. and Miyashita, K. (2009) Evaluation of Recoverable Functional Lipid Components of Several Brown Seaweeds (Phaeophyta) from Japan with special Reference to Fucoxanthin and Fucosterol Contents. Journal of Phycology, 45, 974-980.

http://dx.doi.org/10.1111/j.1529-8817.2009.00706.x

[40] Gerasimenko, N.I., Busarova, N.G. and Moiseenko, O.P. (2010) Seasonal Changes in the Content of Lipids, Fatty Acids, and Pigments in Brown Alga Costaria costata. Russian Journal of Plant Physiology, 57, 205-211. http://dx.doi.org/10.1134/S102144371002007X

[41] Gerasimenko, N.I., Skriptsova, A.V., Busarova, N.G. and Moiseenko, O.P. (2011) Effects of the Season and Growth Stage on the Contents of Lipids and Photosynthetic Pigments in Brown Alga Undaria pinnatifida. Russian Journal of Plant Physiology, 58, 885-891. http://dx.doi.org/10.1134/S1021443711050086

[42] Gerasimenko, N.I., Busarova, N.G. and Logvinov, S.V. (2014) Seasonal Changes in the Content of Lipids and Photosynthetic Pigments in a Brown Alga Saccharina cichorioides. Russian Journal of Plant Physiology, 61, 893-898. http://dx.doi.org/10.1134/S1021443714050082

[43] Kostetsky, E.Y., Goncharova, S.N., Sanina, N.M. and Shnyrov, V.L. (2004) Season Influence on Lipid Composition of Marine Macrophytes. Botanica Marina, 47, 134-139. http://dx.doi.org/10.1515/BOT.2004.013

[44] Bligh, E.G. and Dyer, W.J. (1959) A Rapid Method of Total Lipids Extraction and Purification. Canadian Journal of Biochemistry Physiology, 37, 911-917. http://dx.doi.org/10.1139/059-099

[45] Pollet, S., Ermidou, S., Le Saux, F., Monge, M. and Baumnn, N. (1978) Microanalysis of Brain Lipids: Multiple Two-Dimensional Thin-Layer Chromatography. Journal of Lipid Research, 19, 916-921.

[46] Vaskovsky, V.E., Kostetsky, E.Y. and Vasendin, I.M. (1975) A Universal Reagent for Phospholipid Analysis. Journal of Chromatography, 114, 129-141. http://dx.doi.org/10.1016/S0021-9673(00)85249-8

[47] Radwan, S.S. (1978) Coupling of Two-Dimensional Thin-Layer Chromatography with Gas Chromatography for the Quantitative Analysis of Lipid Classes and their Constituent Fatty Acids. Journal of Chromatographic Science, 16, 538-542. http://dx.doi.org/10.1093/chromsci/16.11.538

[48] Whitlle, S.J. and Casselton, P.J. (1975) The Chloroplast Pigments of the Algal Classes Eustigmatophyceae and Xanthophyceae. I. Eustigmatophyceae. British Phycological Journal, 10, 179-191. http://dx.doi.org/10.1080/00071617500650171

[49] Lichtenthaler, H.K. (1987) [34] Chlorophylls and Carotenoids: Pigments of Photosynthetic Biomembranes. Methods in Enzymology, 148, 350-382.

http://dx.doi.org/10.1016/0076-6879(87)48036-1

[50] Hashimoto, T., Ozaki, Y., Taminato, M., Das, S.K., Mizimo, M., Yoshimura, K., Maoka, T. and Kanozawa, K. (2009) The Distribution and Accumulation of Fucoxanthin and Its Metabolites after Oral Administration in Mice. British Journal of Nutrition, 102, 242-248. http://dx.doi.org/10.1017/S0007114508199007

[51] Prevot, A.F. and Mordret, F.X. (1976) Utilisation des Colonnes Capillaries de Verre Pour L'analyse des Corps Gras par Chromatographie en Phase Gazeuse. Revue Francaise Des Corps Gras, 23, 409-423.

[52] Strànsky, K., Jursík, T. and Vitek, A. (1997) Standard Equivalent Chain Length Values of 
Monoenic and Polyenic (Methylene Interrupted) Fatty Acids. Journal of Separation Science, 20, 143-158. http://dx.doi.org/10.1002/jhrc.1240200305

[53] Rasoarahona, J.R.E. and Ramanoelina, P.A.R. (2008) Muscle Lipids and Fatty Acid Profiles of the Sea Catfish (Arius madagascariensis) in Madagascar Inland Waters. Journal of the American Oil Chemists' Society, 85, 435-440. http://dx.doi.org/10.1007/s11746-008-1211-4

[54] Ulbricht, T.L.V. and Southgate, D.A.T. (1991) Coronary Heart Disease: Seven Dietary Factors. The Lancet, 338, 985-992. http://dx.doi.org/10.1016/0140-6736(91)91846-M

[55] Santos-Silva, J., Bessa, R.J.B. and Santos-Silva, F. (2002) Effects of Genotype, Feeding System and Slaughter Weight on the Quality of Light Lambs. Fatty Acid Composition of Meat. Livestock Product Science, 77, 187-194. http://dx.doi.org/10.1016/S0301-6226(02)00059-3

[56] May-Lin, B.Y. and Ching-Lee, W. (2013) Seasonal Growth Rate of Sargassum Species at Teluk Kemang, Port Dickson, Malaysia. Journal of Applied Phycology, 25, 805-814. http://dx.doi.org/10.1007/s10811-012-9963-5

[57] Floreto, E.A.T., Hirata, H., Ando, S. and Yamasaki, S. (1993) Effects of Temperature, Light Intensity, Salinity and Source of Nitrogen on the Growth, Total Lipid and Fatty Acid Composition of Ulva pertusa Kjellman (Chlorophyta). Botanica Marina, 36, 149-158. http://dx.doi.org/10.1515/botm.1993.36.2.149

[58] Kamnev, A.N., Zolotukhina, E.Y. and Budrin, K.S. (1986) Age-Related Changes in Some Physiological Characteristics of the Brown Alga Sargassum pallidum C. Ag. Russian Journal of Plant Physiology, 33, 930-934.

[59] Yoshida, G., Arima, S. and Terawaki, T. (1998) Growth and Maturation of the "AutumnFruiting Type" of Sargassum horneri (Fucales, Phaeophyta) and Comparisons with the “Spring-Fruiting Type”. Phycological Research, 46, 183-189. http://dx.doi.org/10.1111/j.1440-1835.1998.tb00112.x

[60] Christensen, L.P. (2009) Galactolipids as Potential Health Promoting Compounds in Vegetable Foods. Recent Patents on Food, Nutrition and Agriculture, 1, 50-58. http://dx.doi.org/10.2174/2212798410901010050

[61] Wang, R., Furomoto, T., Motoyama, K., Okazaki, K., Kondo, A. and Fukui, H. (2002) Possible Antitumor Promoters in Spinacia oleracea (Spinach) and Comparison of Their Contents among Cultivars. Bioscience, Biotechnology, and Biochemistry, 66, 248-254. http://dx.doi.org/10.1271/bbb.66.248

[62] Murakami, A., Nakamura, Y., Koshimizu, K. and Ohigashi, H. (1995) Glyceroglycolipids from Citrus hystrix, a Traditional Herb in Thailand, Potently Inhibit the Tumor-Promoting Activity of 12-Otetradecanoylphorbol 13-Acetate in Mouse Skin. Journal of Agricultural and Food Chemistry, 43, 2779-2783. http://dx.doi.org/10.1021/jf00058a043

[63] Furumoto, T., Wang, R., Okazaki, K., Hasan, A.F.M.F., Ali, M.I., Kondoi, A. and Fukui, H. (2002) Anti-Tumor Promoters in Leaves of Jute (Corchorus capsularis and Corchorus olitorius). Food Science and Technology Research, 8, 239-243.

[64] Noda, H., Amano, H., Arashima, K. and Nisizawa, K. (1990) Antitumor Activity of Marine Algae. Hydrobiologia, 204, 577-584. http://dx.doi.org/10.1007/BF00040290

[65] Tsai, C.-J. and Pan, B.S. (2012) Identification of Sulfoglycolipid Bioactivities and Characteristic Fatty Acids of Marine Macroalgae. Journal of Agricultural and Food Chemistry, 60, 8404-8410. http://dx.doi.org/10.1021/jf302241d

[66] Banskota, A.H., Stefanova, R., Sperker, S., Lall, S.P., Craigie, J.S. and Hafting, J.T. (2014) Lipids Isolated from the Red Alga Chondrus crispus Inhibit Nitric Oxide Production. Journal Applied Phycology, 26, 1565-1571. http://dx.doi.org/10.1007/s10811-013-0174-5

[67] Banskota, A.H., Stefanova, R., Sperker, S., Lall, S.P., Craigie, J.S., Hafting, J.T. and Critchley, 
A.T. (2014) Polar Lipids from the Marine Macroalga Palmaria palmata Inhibit Lipopolysaccharide-Induced Nitric Oxide Production in RAW264.7 Macrophage Cells. Phytochemistry, 101, 101-108. http://dx.doi.org/10.1016/j.phytochem.2014.02.004

[68] Gerasimenko, N.I., Martyyas, E.A., Logvinov, S.V. and Busarova, N.G. (2014) Biological Activity of Lipids and Photosynthetic Pigments of Sargassum pallidum C. Agardh. Applied Biochemistry and Microbiology, 50, 73-81. http://dx.doi.org/10.1134/S0003683814010037

[69] Hölzl, G. and Dörmann, P. (2007) Structure and Function of Glycoglycerolipids in Plants and Bacteria. Progress in Lipid Research, 46, 225-243.

http://dx.doi.org/10.1016/j.plipres.2007.05.001

[70] Khotimchenko, S.V. (2002) Distribution of Glyceroglycolipids in Marine Algae and Grasses. Chemistry of Natural Compounds, 38, 223-229. http://dx.doi.org/10.1023/A:1020471709232

[71] Benson, A.A. (1964) Plant Membrane Lipids. Annual Review of Plant Physiology, 15, 1-16. http://dx.doi.org/10.1146/annurev.pp.15.060164.000245

[72] Leech, R.M., Rumsby, M.G. and Thomson, W.W. (1973) Plastid Differentiation, Acyl Lipid, and Fatty Acid Changes in Developing Green Maize Leaves. Plant Physiology, 52, 240-245. http://dx.doi.org/10.1104/pp.52.3.240

[73] Logvinov, S., Gerasimenko, N., Esipov, A. and Denisenko, V.A. (2015) Examination of the Structures of Several Glycerolipids from Marine Macroalgae by NMR and GC-MS. Journal of Phycology, 51, 1066-1074. http://dx.doi.org/10.1111/jpy.12338

[74] Khotimchenko, S.V. and Vaskovsky, V.E. (2000) Distribution of Dihomo-Gammalinolenic Acid within the Thallus of the Brown Alga Sargassum pallidum (Turn.) C. Ag. Botanica Marina, 43, 105-108. http://dx.doi.org/10.1515/BOT.2000.010

[75] Solovchenko, A.E. (2012) Physiological Role of Neutral Lipid Accumulation in Eukaryotic Microalgae under Stress. Russian Journal of Plant Physiology, 59, 167-176. http://dx.doi.org/10.1134/S1021443712020161

[76] Gerasimenko, N.I., Logvinov, S.V., Busarova, N.G. and Martyyas, E.A. (2013) Structure and Biological Activity of Several Classes of Compounds from the Brown Alga Sargassum pallidum. Chemistry of Natural Compounds, 49, 927-929. http://dx.doi.org/10.1007/s10600-013-0781-z

[77] Benning, C. (1998) Biosynthesis and Function of the Sulfolipid Sulfoquinovosyl Diacylglycerol. Annual Review of Plant Physiology and Plant Molecular Biology, 49, 53-75. http://dx.doi.org/10.1146/annurev.arplant.49.1.53

[78] Terasaki, M. and Itabashi, Y. (2003) Glycerolipid Acyl Hydrolase Activity in the Brown Alga Cladosiphon okamuranus Tokida. Bioscience, Biotechnology, and Biochemistry, 67, 1986-1989. http://dx.doi.org/10.1271/bbb.67.1986

[79] Han, T., Han, Y.-S., Kain, J.M. and Häder, D.-P. (2003) Thallus Differentiation of Photosynthesis, Growth, Reproduction, and UV-B Sensitivity in the Green Alga Ulva pertusa (Chlorophyceae). Journal of Phycology, 39, 712-721. http://dx.doi.org/10.1046/j.1529-8817.2003.02155.x

[80] Miyashita, K., Nishikawa, S., Beppu, F., Tsukui, T., Abea, M. and Hosokawa, M. (2011) The Allenic Carotenoid Fucoxanthin, a Novel Marine Nutraceutical from Brown Seaweeds. Journal of the Science of Food and Agriculture, 91, 1166-1174. http://dx.doi.org/10.1002/jsfa.4353

[81] Funga, A., Hamida, N. and Lua, J. (2013) Fucoxanthin Content and Antioxidant Properties of Undaria pinnatifida. Food Chemistry, 136, 1055-1062.

http://dx.doi.org/10.1016/j.foodchem.2012.09.024 
[82] Pohl, P. and Zurheide, F. (1979) Control of Fatty Acid and Lipid Formation in Baltic Marine Algae by Environmental Factors. In: Appelqvist, L.A. and Liljenberg, C., Eds., $A d$ vances in the Biochemistry and Physiology of Plant Lipids, Elsevier, Amsterdam, 427-432.

[83] Harwood, J.L. and Jones, A.L. (1989) Lipid Metabolism in Algae. Advances in Botanical Research, 16, 1-53. http://dx.doi.org/10.1016/S0065-2296(08)60238-4

[84] Jamieson, G.R. and Reid, E.H. (1972) The Component Fatty Acids of Some Marine Algal Lipids. Phytochemistry, 11, 1423-1432. http://dx.doi.org/10.1016/S0031-9422(00)90096-7

[85] Hulbert, A.J., Turner, N., Storlien, L.H. and Else, P.L. (2005) Dietary Fats and Membrane Function: Implication for Metabolism and Disease. Biological Review of Cambridge Philosophical Society, 80, 155-169. http://dx.doi.org/10.1017/S1464793104006578

[86] Hornstra, G. (1999) Lipids in Functional Foods in Relation to Cardiovascular Disease. European Journal of Lipid Science and Technology, 12, 456-466. http://dx.doi.org/10.1002/(sici)1521-4133(199912)101:12<456::aid-lipi456>3.0.co;2-1

[87] Chen, R., Lochmann, R., Goodwin, A., Praveen, K., Dabrowski, K. and Lee, K.J. (2004) Effects of Dietary Vitamins C and E on Alternative Complement Activity, Hematology, Tissue Composition, Vitamin Concentrations and Response to Heat Stress in Juvenile Golden Shiner (Notemigonus crysoleucas). Aquaculture, 242, 553-569. http://dx.doi.org/10.1016/j.aquaculture.2004.09.012

[88] Hunter, B.J. and Roberts, D.C.K. (2000) Potential Impact of the Fat Composition of Farmed Fish on Human Health. Nutrition Research, 20, 1047-1058. http://dx.doi.org/10.1016/S0271-5317(00)00181-0

[89] Albertazzi, P. and Coupland, K. (2002) Polynsaturated Fatty Acids. Is There a Role in Postmenopausal Osteoporosis Prevention? Maturitas, 42, 13-22. http://dx.doi.org/10.1016/S0378-5122(02)00022-1

[90] Yamazaki, K., Fujikawa, M., Hamazaki, T., Yano, S. and Shono, T. (1992) Comparison of the Conversion Rates of [alpha] Linolenic Acid (18:3n-3) and Stearidonic Acid (18:4n-3) to Longer Polyunsaturated Fatty Acids in Rats. Biochimica et Biophysica Acta, 1123, 18-26.

[91] Whelan, J. (2009) Dietary Stearidonic Acid Is a Long Chain (n-3) Polyunsaturated Fatty Acid with Potential Health Benefits. Journal of Nutrition, 139, 5-10.

http://dx.doi.org/10.3945/jn.108.094268

[92] Guil-Guerrero, J.L. (2007) Stearidonic Acid (18:4n-3): Metabolism, Nutritional Importance, Medical Uses and Natural Sources. European Journal of Lipid Science and Technology, 109, 1226-1236. http://dx.doi.org/10.1002/ejlt.200700207

[93] Colombo, M.L., Risè, P., Giavarini, F., De Angelis, L., Galli, C. and Bolis, C.L. (2006) Marine Macroalgae as Sources of Polyunsaturated Fatty Acids. Plant Foods for Human Nutrition, 61, 67-72.

[94] Kumari, P., Kumar, M., Gupta, V., Reddy, C.R.K. and Jha, B. (2010) Tropical Marine Macroalgae as Potential Sources of Nutritionally Important PUFAs. Food Chemistry, 120, 749-757. http://dx.doi.org/10.1016/j.foodchem.2009.11.006

[95] Martin, A. (2001) Apports Nutritionnels Conseilles pour la Population Francaise. 3rd Edition, Lavoisier, Paris.

[96] Simopoulos, A.P. (1989) Summary of the NATO Advanced Research Workshop on Dietary Omega 3 and Omega 6 Fatty Acids: Biological Effects and nutritional Essentiality. Journal of Nutrition, 119, 521-528.

[97] Tonial, I.B., de Oliveira, D.F., Coelho, A.R., Matsushita, M., Coró, F.A.G., de Souza, N.E. and Visentainer, J.V. (2014) Quantification of Essential Fatty Acids and Assessment of the Nutritional Quality Indexes of Lipids in Tilapia Alevins and Juvenile tilapia Fish (Oreoch- 
romis niloticus). Journal of Food Research, 3, 105-114.

http://dx.doi.org/10.5539/jfr.v3n3p105

[98] Roche, H.M. (2006) Nutrigenomics-New Approaches for Human Nutrition Research. Journal of the Science of Food and Agriculture, 86, 1156-1163.

http://dx.doi.org/10.1002/jsfa.2484

[99] Palanca, V., Rodriguez, E., Señorans, J. and Reglero, G. (2006) Bases Científicas Para el Desarrollo de Productos Cárnicos Funcionales con Actividad Biológica Combinada. Nutricion Hospitalaria, 21, 199-202.

[100] Sastry, P.S. (1974) Glycosyl Glycerides. Advances in Lipid Research, 12, 251-310. http://dx.doi.org/10.1016/B978-0-12-024912-1.50013-2

[101] Takahashi, Y., Itabashi, Y., Suzuki, M. and Kuksis, A. (2001) Determination of Stereochemical Configuration of the Glycerol Moieties in Glycoglycerolipids by Chiral Phase HighPerformance Liquid Chromatography. Lipids, 36, 741-748.

http://dx.doi.org/10.1007/s11745-001-0780-y

[102] Chapkin, R.S. and Coble, K.J. (1991) Utilization of Gamma Linolenic Acid by Mouse Peritonea Macrophages. Biochimica et Biophysica Acta, 1085, 365-370.

Submit or recommend next manuscript to SCIRP and we will provide best service for you:

Accepting pre-submission inquiries through Email, Facebook, LinkedIn, Twitter, etc. A wide selection of journals (inclusive of 9 subjects, more than 200 journals)

Providing 24-hour high-quality service

User-friendly online submission system

Fair and swift peer-review system

Efficient typesetting and proofreading procedure

Display of the result of downloads and visits, as well as the number of cited articles Maximum dissemination of your research work

Submit your manuscript at: http://papersubmission.scirp.org/

Or contactojms@scirp.org 